\title{
Front Matter: Volume 8075
}

, "Front Matter: Volume 8075," Proc. SPIE 8075, Harnessing Relativistic Plasma Waves as Novel Radiation Sources from Terahertz to X-Rays and Beyond II, 807501 (25 May 2011); doi: 10.1117/12.900264

SPIE. Event: SPIE Optics + Optoelectronics, 2011, Prague, Czech Republic 


\section{PROCEEDINGS OF SPIE}

\section{Harnessing Relativistic Plasma Waves as Novel Radiation Sources from Terahertz to $X$-Rays and Beyond II}

Dino A. Jaroszynski

Editor

20-21 April 2011

Prague, Czech Republic

Sponsored and Published by

SPIE

Cooperating Organisations

ELI Beamlines

HiPER 
The papers included in this volume were part of the technical conference cited on the cover and title page. Papers were selected and subject to review by the editors and conference program committee. Some conference presentations may not be available for publication. The papers published in these proceedings reflect the work and thoughts of the authors and are published herein as submitted. The publisher is not responsible for the validity of the information or for any outcomes resulting from reliance thereon.

Please use the following format to cite material from this book:

Author(s), "Title of Paper," in Harnessing Relativistic Plasma Waves as Novel Radiation Sources from Terahertz to X-Rays and Beyond II, edited by Dino A. Jaroszynski, Proceedings of SPIE Vol. 8075 (SPIE, Bellingham, WA, 2011) Article CID Number.

ISSN 0277-786X

ISBN 9780819486653

Published by

SPIE

P.O. Box 10, Bellingham, Washington 98227-0010 USA

Telephone +1 3606763290 (Pacific Time) · Fax +1 3606471445

SPIE.org

Copyright (C) 2011, Society of Photo-Optical Instrumentation Engineers

Copying of material in this book for internal or personal use, or for the internal or personal use of specific clients, beyond the fair use provisions granted by the U.S. Copyright Law is authorized by SPIE subject to payment of copying fees. The Transactional Reporting Service base fee for this volume is $\$ 18.00$ per article (or portion thereof), which should be paid directly to the Copyright Clearance Center (CCC), 222 Rosewood Drive, Danvers, MA 01923. Payment may also be made electronically through CCC Online at copyright.com. Other copying for republication, resale, advertising or promotion, or any form of systematic or multiple reproduction of any material in this book is prohibited except with permission in writing from the publisher. The CCC fee code is 0277-786X/11/ \$18.00.

Printed in the United States of America.

Publication of record for individual papers is online in the SPIE Digital Library.

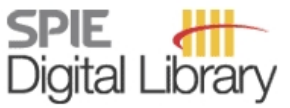

SPIEDigitalLibrary.org

Paper Numbering: Proceedings of SPIE follow an e-First publication model, with papers published first online and then in print and on CD-ROM. Papers are published as they are submitted and meet publication criteria. A unique, consistent, permanent citation identifier (CID) number is assigned to each article at the time of the first publication. Utilization of CIDs allows articles to be fully citable as soon as they are published online, and connects the same identifier to all online, print, and electronic versions of the publication. SPIE uses a six-digit CID article numbering system in which:

- The first four digits correspond to the SPIE volume number.

- The last two digits indicate publication order within the volume using a Base 36 numbering system employing both numerals and letters. These two-number sets start with 00, 01, 02, 03, 04, $05,06,07,08,09,0 A, 0 B \ldots 0 Z$, followed by 10-1Z, 20-2Z, etc.

The CID number appears on each page of the manuscript. The complete citation is used on the first page, and an abbreviated version on subsequent pages. Numbers in the index correspond to the last two digits of the six-digit CID number. 


\section{Contents}

$\checkmark$ Conference Committee

QED+HIGH FIELD PHYSICS I

807503 Analytical model for QED cascade development in rotating superstrong electric field (Invited Paper) [8075-02]

E. N. Nerush, I. Yu. Kostyukov, Institute of Applied Physics (Russian Federation)

807504 QED effects and radiation generation in relativistic laser plasma (Invited Paper) [8075-03]

I. Yu. Kostyukov, E. N. Nerush, V. F. Bashmakov, Institute of Applied Physics (Russian

Federation)

807505 QED and nuclear effects in strong optical and x-ray laser fields (Invited Paper) [8075-04] A. Di Piazza, A. Pálffy, W.-T. Liao, K. Z. Hatsagortsyan, C. H. Keitel, Max-Planck-Institut für Kernphysik (Germany)

\section{QED+HIGH FIELD PHYSICS II}

807507 Intense, brilliant micro Y-beams in nuclear physics and applications (Invited Paper) [8075-06]

D. Habs, Ludwig-Maximilians Univ. München (Germany) and Max-Planck-Institut für Quantenoptik (Germany); S. Gasilov, C. Lang, P. G. Thirolf, Ludwig-Maximilians Univ. München (Germany); M. Jentschel, Institut Laue Langevin (France); R. Diehl, Max-Planck-Institut für Extraterrestrische Physik (Germany); C. Schroer, Technische Univ. Dresden (Germany); C. P. J. Barty, Lawrence Livermore National Lab. (United States);

N. V. Zamfir, National Institute of Physics and Nuclear Engineering (Romania)

807509 Radiation friction modeling in superintense laser-plasma interactions (Invited Paper) [8075-08]

A. Macchi, M. Tamburini, Istituto Nazionale di Ottica, CNR (Italy) and Univ. di Pisa (Italy);

F. Pegoraro, Univ. di Pisa (Italy); T. V. Liseykina, Univ. Rostock (Germany)

\section{QED+HIGH FIELD PHYSICS III}

8075 OB Linear and non-linear waves in a cold Born-Infeld plasma (Invited Paper) [8075-10] D. A. Burton, H. Wen, Lancaster Univ. (United Kingdom) and Cockcroft Institute (United Kingdom)

\section{RAMAN AMPLIFICATION IN PLASMA}

8075 OE Raman amplification in plasma (Invited Paper) [8075-35]

R. A. Cairns, Univ. of St. Andrews (United Kingdom) 
8075 OG Experimental investigation of chirp pulse Raman amplification in plasma (Invited Paper) [8075-15]

X. Yang, G. Vieux, E. Brunetti, J. P. Farmer, B. Ersfeld, S. M. Wiggins, R. C. Issac, G. H. Welsh, D. A. Jaroszynski, Univ. of Strathclyde (United Kingdom)

$8075 \mathrm{OH} \quad$ Wavebreaking as a limit for Raman amplification (Invited Paper) [8075-16]

J. P. Farmer, B. Ersfeld, D. A. Jaroszynski, Univ. of Strathclyde (United Kingdom)

FREE-ELECTRON LASERS I

8075 OL A new XUV-source for seeding a FEL at high repetition rates (Invited Paper) [8075-20]

A. Willner, Deutsches Elektronen-Synchrotron (Germany) and Helmholtz-Institute Jena

(Germany); M. Schulz, Deutsches Elektronen-Synchrotron (Germany) and Univ. of Hamburg

(Germany); R. Riedel, Helmholtz-Institute Jena (Germany) and Univ. of Hamburg (Germany);

M. Yeung, T. Dzelzainis, Queens Univ. (United Kingdom); C. Kamperidis, M. Bakarezos,

Technological Educational Institute of Crete (Greece); D. Adams, Queens Univ. (United

Kingdom); V. Yakovlev, Max-Planck-Institute for Quantum Optics (Germany);

J. Rönsch-Schulenburg, Univ. of Hamburg (Germany); B. Dromey, Queens Univ. (United

Kingdom); N. Papadogiannis, M. Tatarakis, Technological Educational Institute of Crete

(Greece); S. Düsterer, S. Schreiber, B. Faatz, Deutsches Elektronen-Synchrotron (Germany);

M. Drescher, J. Rossbach, Univ. of Hamburg (Germany); M. Zepf, Queens Univ. (United

Kingdom); F. Tavella, Helmholtz-Institute Jena (Germany)

\section{FREE-ELECTRON LASERS II}

807500 Laser-driven radiation sources in the ALPHA-X project (Invited Paper) [8075-23]

S. M. Wiggins, J. G. Gallacher, Univ. of Strathclyde (United Kingdom); H.-P. Schlenvoigt, Friedrich-Schiller-Univ. Jena (Germany) and LULI-École Polyłechnique (France);

H. Schwoerer, Friedrich-Schiller-Univ. Jena (Germany) and Univ. of Stellenbosch (South Africa); G. H. Welsh, R. C. Issac, E. Brunetti, G. Vieux, R. P. Shanks, S. Cipiccia, M. P. Anania, G. G. Manahan, C. Aniculaesei, A. Subiel, D. W. Grant, A. J. W. Reitsma, B. Ersfeld, M. R. Islam, D. A. Jaroszynski, Univ. of Strathclyde (United Kingdom)

$80750 Q$ Steady-state description of an ion channel free-electron laser with varying betatron amplitude (Invited Paper) [8075-25]

B. Ersfeld, R. Bonifacio, S. Chen, M. R. Islam, Scottish Universities Physics Alliance (United Kingdom) and Univ. of Strathclyde (United Kingdom); P. W. Smorenburg, Eindhoven Univ. of Technology (Netherlands); D. A. Jaroszynski, Scottish Universities Physics Alliance (United Kingdom) and Univ. of Strathclyde (United Kingdom)

\section{BETATRON, PLASMA UNDULATORS \& HARMONIC GENERATION II}

8075 OY Gamma-ray generation using laser-accelerated electron beam (Invited Paper) [8075-33] S. H. Park, Korea Atomic Energy Research Institute (Korea, Republic of); H.-H. Lee, Korea Advanced Institute of Science and Technology (Korea, Republic of); K. Lee, Y.-H. Cha, J.-Y. Lee, Korea Atomic Energy Research Institute (Korea, Republic of); K.-N. Kim, Korea Atomic Energy Research Institute (Korea, Republic of) and Kongju Univ. (Korea, Republic of); Y. U. Jeong, Korea Atomic Energy Research Institute (Korea, Republic of)

Author Index

iv 


\title{
Conference Committee
}

\author{
Symposium Chairs
}

Miroslav Hrabovský, Palacký University Olomouc (Czech Republic)

Wolfgang Sandner, Max-Born-Institut für Nichtlineare Optik und Kurzzeitspektroskopie (Germany) and Laserlab Europe

Bahaa Saleh, CREOL, The College of Optics and Photonics, University of Central Florida (United States)

Jan Rídký, Institute of Physics of the ASCR, v.v.i. (Czech Republic)

Symposium Honorary Chair

Jan Peřina, Sr., Palacký University Olomouc (Czech Republic)

Conference Chair

Dino A. Jaroszynski, University of Strathclyde (United Kingdom)

Conference Cochair

Antoine Rousse, Ecole Nationale Supérieure de Techniques Avancées (France)

Programme Committee

Christopher E. Clayton, University of California, Los Angeles (United States)

Florian J. Grüner, Ludwig-Maximilians-Universität München (Germany)

Alexander Pukhov, Heinrich-Heine-Universität Düsseldorf (Germany)

Luis O. Silva, Universidade Técnica de Lisboa (Portugal)

Toshi Tajima, Ludwig-Maximilians-Universität München (Germany)

S. Mark Wiggins, University of Strathclyde (United Kingdom)

Nicolae-Victor Zamfir, National Institute of Physics and Nuclear Engineering (Romania)

Matthew Zepf, Queen's University Belfast (United Kingdom)

Session Chairs

1 QED+High Field Physics I

Dino A. Jaroszynski, University of Strathclyde (United Kingdom) 
QED+High Field Physics II

Toshiki Tajima, Ludwig-Maximilians-Universität München (Germany)

3 QED+High Field Physics III

Silvia Cipiccia, University of Strathclyde (United Kingdom)

4 Raman Amplification in Plasma

Luis O. Silva, Universidade Técnica de Lisboa (Portugal)

5 Free-Electron Lasers I

Florian J. Grüner, Ludwig-Maximilians-Universität München (Germany)

6 Free-Electron Lasers II

Alexander Pukhov, Heinrich-Heine-Universität Düsseldorf (Germany)

7 Betatron, Plasma Undulators \& Harmonic Generation I

Dino A. Jaroszynski, University of Strathclyde (United Kingdom)

8 Betatron, Plasma Undulators \& Harmonic Generation II

S. Mark Wiggins, University of Strathclyde (United Kingdom) 